\title{
الأوبئة وآثارها في التراث العربي
}

\section{Epidemics and Their Effects in the Arab Heritage} محمود مهاي

\section{mmm.badwy@hotmail.com}

\section{ملخص البحث:}

لا يزال التراث العربي حتى يومنـا هذا كنزًا لم تفتح كل أغلاقه لنتمكن من

اكتثـاف ما تحويها بطون مخطوطاته، وما أفرزته عقول علمائه، وما سـاهموا به في مسيرة الحضـارة الإنسـانية، وما نشر منه حتى يومنا هذا يمنحنا الثقة في أن جهود علمائنا القدامى كانت في حينها نموذجًا للإبداع والابتكار والتقدم، والنظر إلى التراث العربي الإســـلامي لابد وأن تراعى فيه معايير زمانه والإمكانات التي أتيحت لعلمائه آنذاك حتى لا نصـــدر أحكاما جائرة تغمط علماءنا حقهم، وتقلل من جهدهم، وتســـفه آراءهم، وكتب التراث العربي تتاولت في كثير من فنونها الحديثَ عن الأمراض والأوبئة وأسبابها، وأفرد لها بعض العلماء مؤلفات مستقلة، كما أدرجها بعض العلماء ضـــمن مؤلفاتهم الطبية، واهتم العلماء بملوثات الهواء والماء وكيفية إصــلاحهما، وتحدثوا عن البيئة وســلامتها كعامل هام من عوامل حفظ الصــة، ولم تخلُ كتب التاريخ من الحديث عن الأوبئة وآثارها الاجتماعية والاقتصـادية بل والعسكرية الخطيرة، كما نظم الثـعراء، وسطَّر الأدباء يصـفون مشــاعر الناس وآلامهم جراء ما حاق بهم من الوباء، وقد تبين بما لا يدع مجالا للثــك أن كثيرًا من النتائج العلمية القديمة التي توصـلـل إليها علماؤنا في مجال

* الخبير بمركز تحقيق التراث العربي بجامعة مصر للعلوم والتكنولوجيا، ونائب مدير المركز. 
باب للأمراض وكيفية معالجته والوقاية من أضـــراره قد أقرها العلم التلوث المســــبـ الحديث.

الكلمات المفتاحية: التراث، الأوبئة، البيمارستانات، الحارث بن كلدة، الحجر الصحي.

\section{Abstract:}

The Arab heritage remains up till now a treasure that has not been fully opened so that we can discover what is contained in its manuscripts. And what the minds of his scholars produced, and what they contributed in the development of human civilization. And what has been published from it to this day gives us confidence that the efforts of our old scholars were at that time a model for creativity, innovation and progress, and looking at the Arab Islamic heritage must take into account the standards of its time and the capabilities that were available at the time so that we do not issue unfair judgments that Underestimate our scholars' rights, reduce their efforts, and ridicule their opinions, and Arab heritage books dealt in many of their arts with talking about diseases and epidemics and their causes, and some scholars singled out independent books for them, as some scholars included them in their medical books. History books were not free from talking about epidemics and their social, economic and even dangerous military effects, as poets wrote, and prosaist wrote describing people's feelings and pain as a result of the epidemic. In the field of disease-causing 
pollution and how to treat it and prevent its damages, modern science has approved it.

\section{Keywords:}

\section{Heritage, Epidemics, Bimaristanat, Al-Harith Bin Kalda, Quarantine.}

\section{تمهيد:}

في غمرة ما يعيشه الناس من هلع وفزع وترقب جراء اجتياح وباء "كورونا" للعالم شرقه وغربه، وفي خضم ما يبذل من جهود على المستويين الطبي والحكومي لتفادي مضار هذا الوباء، ومع التغيرات التي طرأت على بعض السلوكيات الاجتماعية، والآثار السلبية للوباء اقتصاديًا، فقد يظن البعض أن الأوبئة التي تضرب البشرية بين الحين والآخر وما يصاحبها من تغيرات هي مشكلة عصرية، لكنها في الحقيقة كانت ظاهرة صحية واجتماعية واقتصادية قديمة أرقت العلماء في شتى أنحاء المعمورة منذ أن هاجمت الأوبئة الناس، فقاسوا ويلاتها، وصارت تحصد أرواحهم حصدًا بلا هوادة.

ولتقليب صفحات التراث العربي الذي يمثل ذاكرة الأمة للوقوف على جهود

علمائنا المبذولة في مواجهة أخطار هذا العدو الخفي الذي لا ينذر بقدومه، ولا يرحم شيخًا ضعيفًا ولا طفلا صغيرًا، وما وقفوا عليه من أسباب حدوثه، وما نادوا به وقاية منه، وما وصفوه للمصابين من أدوية، وما سجله مؤرخونا وأدباؤنا القدامى من آثاره الاجتماعية والاقتصادية الرهيبة على المجتمع الموبوء، ينبغي علينا أوَّلًا ألا نتعجل في حكمنا على تلك الجهود بالتقليل منها، أو تسفيه آراء أصحابها، كما ينبغي أن نضع تلك الجهود في نصابها الصحيح، وأن ندرسها ضمن ظروفها 
الزمانية، وحسب الإمكانات التي أتيحت للعلماء آنذاك، حتى نتمكن من الوصول إلى حكم عادل دون مبالغة أو تهوين، فالمقارنة بين النتائج العلمية التي توصل إليها المحدثون بمعاملهم ومختبراتهم وأدواتهم المتقدمة وإمكاناتهم المادية العالية، وما يتوفر لهم من تواصل وتثاور وتجارب لا وجه لمقارنتها بجهود القدامى المحدودة الإمكانات المعملية والمادية. ومع كل ذلك فسأحاول في هذا البحث أن أُبِّن إلى أي مذَى خطا علماء الحضارة الإسلامية بأفكارهم وآرائهم وأدواتهم البدائية خطوات لم يعرفها علماء اليونان، وأنهم أتوا بما لا يزال المحدثون يُقِرُِونه ويؤيدونه، وحذروا مما لا يزال التحذير منه قائمًا، وفي ذلك تأكيد على أن العلوم لا تتمو طفرة، لكنها كالأبنية الثامخة لا ترتفع قمها دون أسس وطوابق تسمو شيئًا فشيئًا حتى تصل إلى القمة.

إن أحداث الماضي ونكباته لا تخلو من دلالات وعظات وعبر وفوائد، يمكن الإفادة منها بعد تخليصها مما لا يوافق النتائج الصحيحة التي توصلت إليها أبحاث العلماء المحدثين.

\section{مفهوم الوباء :}

الْوَبَأُ، محركةً: الطاعون، أو كل مرض عام (1).

وقيل: الوباء العام هو الذي يقال لله مركامركى: أي الموت العام، وقال الأطباء هو فساد يعرض لجوهر الهواء لأسباب سماوية أو أرضية(2). فقوله "مرض عام" يفيد بأنه مرض يصيب أعدادًا كبيرة في زمن واحد ومكان واحد، وأن عموميته تتأتى من انتشاره السريع بواسطة العدوى. 
والتعريف الثاني: يذكر سببًا من أسباب حدوث الوباء، ألا وهو فساد الهواء، وذلك بأن تصير طبيعته غير صالحة للحياة الصحيحة، والمراد بفساد الهواء تلوثه لأسباب سماوية كالتقلبات المناخية، وأرضية كانتشار الروائح الكريهة والعفونات الناجمة عن تلوث البيئة. وهذه التعريفات لا تختلف كثيرًا عن التعريفات الحديثة التي تقيد بأنه انتشار سريع ومفاجئ لمرض ما في بيئة ما، وإن كانت حركة التنقل والتواصل المباشر بين الناس اليوم ساهمت بشكل كبير في انتشاره بشكل أوسع وأسرع في شتى أرجاء المعمورة حتى صلار الوباء عالميَّا. وإذا كان البعض قديمًا كان يعرف الوباء بأنه الطاعون كالخليل بن أحمد الفراهيدي(175هـ/791م) (3) فقد بيَّن ابن حجر العسقلاني(ت1852هـ/1448م) نقلا عن القاضي عياض، أنهما ليسا مترادفين، إنما بينهما عموم وخصوص، فكل طاعون وباءُ، وليس كل وباء طاعونًا(4). ثم يدلل ابن حجر على التثريق بينهما بتحليله لحديثين شريفين، أولهما: قال رسول الله لا يدخلها الطاعون ولا الاجال(5) ". والثاني: عن عائشة-رضي الله عنها- قالت: "قِدمنا المدينة وهي أوبأ أرض الله... (6) " أي كثيرة انتشار الحمى بها. ثم يعلق قائلا: فلو كان الطاعون هو الوباء لتعارض الحديثان، لكن لا تعارض بينهما؛ لأن الطاعون أخص من الوباء (7). 
وهذا التفريق بين الطاعون والوباء يدل على أن العلماء المسلمين قد عرفوا

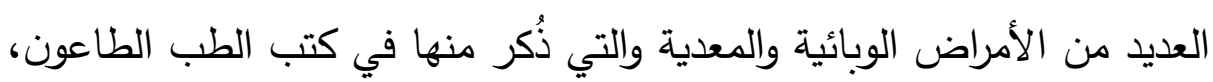
والسل، والجذام، والحصبة، والجدري، والجرب، وغيرها.

\section{أسباب الأوبئة:}

قبل الحديث عن أسباب الأوبئة التي حفلت بها كتب الطب التراثية لابد من

الإثارة إلى أن علماءنا عُنوا قبل ذلك بالحديث عما يحفظ الصحة الصوبه الصوجودة، ويقيها الأمراض المتوقعة وغير المتوقعة، فالوقاية كما قيل خير من العلاج، ودرو المفاسد إندانس

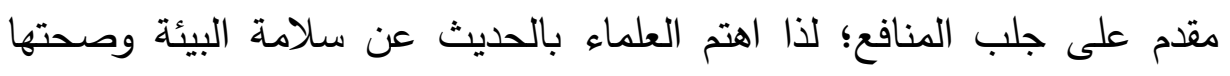

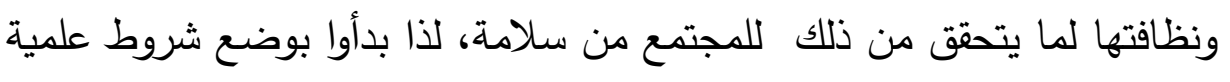

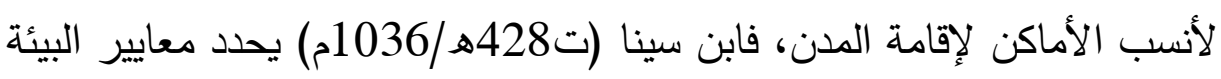

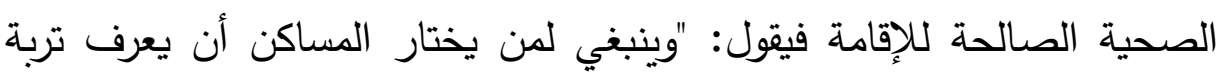

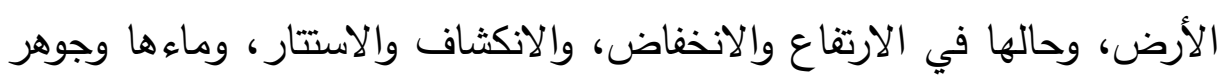

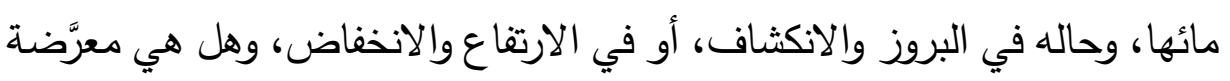

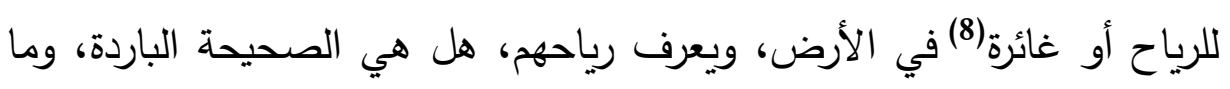

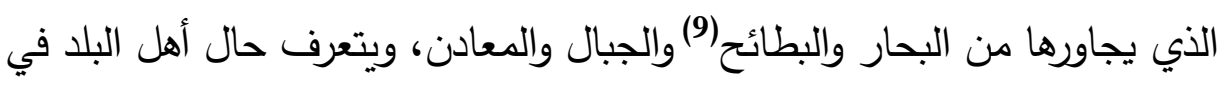

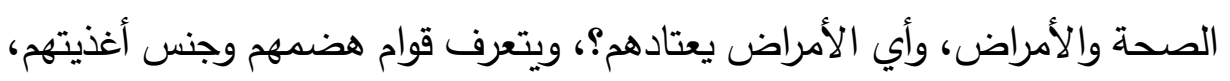

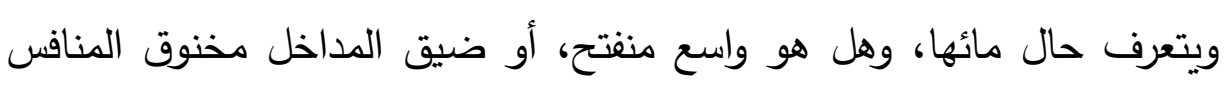

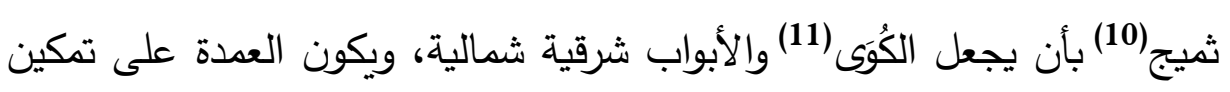

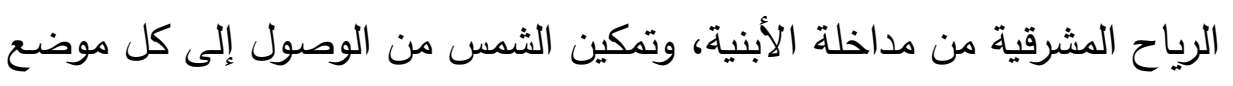
فيها، فإنها هي الُْصْصِحة للهواء (12) ".

د/ محمود مهاي (الأوبئة وآثارها في التراث (لعربي) 
وجُل كلام ابن سينا يتقق مع ما يوصي به العلماء اليوم، فالتربة الثابتة التي لا تتحول إلى غبار تثيره الرياح فيضر بمستشقه، والماء الجاري الذي لا يخالط المعادن ولا ما يغير طبيعته، والمساكن ذات الأبواب والنوافذ الشرقية والثمالية التي تستقبل الهواء البارد صباحًا ومساءً فيتجدد هواؤها الداخلي، وضرورة دخول أشعة الشمس للمسكن فتطهره، كل ذلك مما أقر العلماء حديثًا بصلاحيته وضرورة توفيره في البيئة الصحية التي تحد من انتشار الأمراض والأوبئة، كما أنه من المؤكد أن ضوء الثمس عامل هام في بعث النشاط والحيوية البدنية والنفسية. ويقول ابن خلدون (808هـ/1405م)في حديثه عما يجب مراعاته في أوضاع المدن وما يحدث إذا أهملت تلك الضوابط:"ومما يراعى في ذلك للحماية من الآفات السماوية طيب الهواء للسلامة من الأمراض، فإن الهواء إذا كان راكدًا خبيثًا أو مجاورًا للمياه الفاسدة أو مناقع متعفنة أو مروج خبيثة أسرع إليها العفن من مجاورتها، فأسرع المرض للحيوان الكائن فيه لا محالة.. والمدن التي لم يراع فيها طيب الهواء كثيرة الأمراض في الغالب(13) ". وكلام ابن خلدون يتفق مع ما ذهب إليه ابن سينا، بل ويركز على نقاء

$$
\text { الهواء الذي إذا فسد كان سببا في الأمراض. }
$$

ورأى العلماء أن البيمارستانات(المستشفيات) التي يعالج فيها المرضى لا بد الد أن تبنى في أماكن صحية تتوفر فيها الضوابط السابقة؛ لتساعد على سرعة شفاء المرضى، وإلا زاد بها الضرر، وها هو عضد الدولة يجمع الأطباء لاستشارتهم في أنسب موضع يقيم فيه بيمارستانا، وكان الرازي(311هـ/923م) في جملة الحاضرين، فحدد كل واحد من الحاضرين موضعًا، إلا الرازي فإنه لم يتعجل الرأي، 
لكنه أمر بعض غلمانه أن يعلّق في كل ناحية من جانبَي بغداد قطعة من اللحم، ثم اختار الجهة السليمة بيئيَّا وصحيَّا، وهي التي لم يسرع فيها الفساد إلى اللحم؛ لأنها أنقى هواءً وأعدل حرارةً(14).

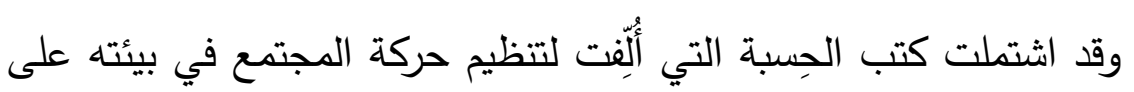
مستوى كافة جوانب حياته على الكثير من الضوابط التي تكفل للجميع السلامة والأمن، فكانت الدولة تكلف المحتسب، وهو المراقب لحركة الناس وتصرفاتهم في بنائهج، وأسواقهم، ومهنهم، والتزامهر بالتعليمات التي أقرتها الدولة، وتوقيع العقوبة المقررة على من يخالف التعاليم، ومنها التعاليم الموضوعة للسلامة البيئية، ومن ذلك:

* أمْر أصحاب الميازبب(15) أن يجعلوا عوضًا عنها مسيلا محفورا مُكَلَّسًا، وكل من كان في داره مخرج للوستخ إلى الطريق فإنه مكلف بسده في الصيف. وهذا الأمر يؤكد إدراك المسئولين لمخاطر المياه المنصرفة بالطرق، وأن طول مقامها يؤدي إلى تعفنها وانتشار الحشرات الضارة حولها، وأن الصيف فصل ترتفع فيه الحرارة، ومع ارتفاع الحرارة تزداد الأبخرة الفاسدة، وتكثر الحشرات الضارة الناقلة لنأمراض. ومن الجميل أنْ نرى أنَّ التحذير قد اقترن بالحل البديل، وهو إنثاء ما يشبه القنوات الصغيرة المبطنَّة بالمواد التي لا تسمح للماء بالتسرب إلى باطن الأرض، لكنها تتقل المياه بسرعة بعيدًا عن البيوت والطرق.

*"إبعاد حوانيت الخبازين والطباخين والحدادين عن البيوت ومحال بيع الأدوية والعطارة حتى لا تضر الأدخنة الناس، وتفسد بضاعة التجار. 
ولا يخفى على أحد أن الأدخنة مصدر من مصادر تلوث الهواء الذي يستشقه الناس فيسبب للكثير منهم الأمراض، ويمكن أن يؤدي إلى فساد البضاعة المكثوفة المعروضة باختلاطها بروائح الدخان الكريهة، وقد كان بين هذه البضاعة أعشاب تباع كدواء يعالج به المرضى.

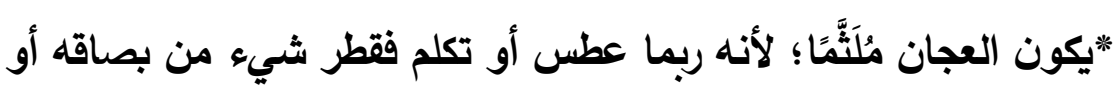
مُخَاطه في العجين (16). وقد أثبت العلم الحديث خطورة العطاس والمخاط الصادرين عن مريض بمرض معد، فالرذاذ المنفوث مع العطاس من فم مريض بمرض معد يحمل عددا هائلا من الميكروبات الناقلة للمرض، ولا نزال نرى الحض على تغطية الأنف والفم (باللثام، وهو الكمامة) لما لهما من دور في تصدير واستقبال الميكروبات. ويلاحظ مما سبق عناية العلماء بأهم عنصرين تتوقف عليهما صحة الإنسان، بل وحياته، وهما الهواء و الماء فكان التركيز على سلامتهما من التلوث، والعمل على نقائهما دائمًا، ونحن ندرك إلى أي مدًى يمكن لهذين العنصرين إذا تلوثا بمكونات طبيعية أو بحمل أسباب المرض من المصابين بأمراض معدية أن يحدثا الكثير من الأمراض والأوبئة. إذًا فما ملوثات الهواء والماء التي رصدها العلماء؟، وكيف عالجوها؟، وهل هناك أسباب أخرى عرفها علماء الحضارة العربية؟ 


\section{1 الهواء الوبائي:}

ركز العلماء في وصف الهواء الفاسد المسبب للأمراض على تغير صفاته الفيزيائية باحتوائه على مواد ذات تأثير ضار من المواد المتصاعدة إليه كالأبخرة الفاسدة وغيرها.

وعرف العلماء الهواء الوبائي بأ نه الهواء الذي خرج عن حد الاعتدال في جملة طبعه، أي أن جميع صفاته قد نالها الفساد، فصار وبائيَّا ناقلا للأمراض. وقد تتبه العلماء لحقيقة هامة وهي أن الغذاء والشراب الطبيعيين لا يمكن أن يكونا سببَا في الأمراض الوبائية العامة، إنما يستطيع الهواء أن يفعل ذلك لعمومه

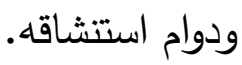

يقول التميمي(ت بعد390-999م): "والأمراض العامية أكثرها حدوثًا إنما يكون من أجل الهواء المحيط بالأبدان، وذلك أن المرض العام على أهل مدينة معًا أو على أهل بلد من طعام عام ليس هو مما يتفق كثيرًا، وكذلك لا يكاد يكون المرض العام من شراب عام، ولا من تعب عام، فأما الهواء المحيط بالأبدان فإنه متى أفرطت فيه الحرارة أو البرودة أو اليبس أو الرطوبة فإنه يكدر ويفَند فيُفْسِد اعتدال أمزجة الأبدان التي هي عماد الصحة، فأما الأسباب الأخر ، فإنها ليست تستولي على جميع الناس كاستيلاء الهواء على أبدانهم، ولا هي مما يدوم ملاقاة الأبدان ليلا ونهارًا، فأما الهواء فإنه وحده دون سائر تلك يحيط بجميع الأبدان، ولسنا ننفك من اجتذابه بالاستنشاق في حال التنفس(17) ". ويشبه عمل الرئة في التنفس بعملية الإحراق المعروفة، فيرى أن الهواء الذي نتنفسه إذا لم يتجدد فإنه يؤدي إلى الاختناق، وما هذا إلا كالنار التي لا يتغير 
الهواء المحيط بها فتتطفئ. وهذا التشبيه صحيح لدرجة بعيدة، فعملية التنفس تكون بالثهيق وهو استتشاق الأكسجين، والزفير وهو إخرج ثاني أكسيد الكربون، وعدم تجدد الهواء يؤدي إلى امتلاء المكان بثاني أكسيد الكربون السام، والنار تحتاج للأكسجين كي تشتعل، فإن خلا المحيط بها منه انطفأت.

\section{2-2 الهواء الحيد:اء}

عرف ابن سينا الهواء الجيد الصالح للتنف الذي يحفظ للمرء حياته، ولا يسبب له الأمراض بأنه" الهواء الذي لا يخالطه من الأبخرة والأدخنة شيء غريب، وهو مكشوف للسماء غير محقون للجدران والسقوف، لا يخالطه بخار بطائح وآجام وخنادق وأراضين...ولا محقون في جدران حديثة العهد بالصهاريج ونحوها لم

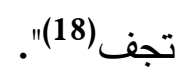

فابن سينا يذكر من بين صفات الهواء الجيد ألا يكون محقونا بين الجدران والأسقف، وهو هواء الأماكن المغلقة التي لا يتجدد هواؤها، وألا يكون محقونا في الجدران الرطبة لتحمل الهواء بالأبخرة الرطبة المنبعثة منها عند جفافها، وهذا صحيح إلى حد بعيد.

\section{3-مفسدات الهواء ومسبيات الوباء:}

رصد العلماء عديدًا من العوامل التي تساهم في فساد الهواء وتلوثه، ومنها:

1- التغيرات الفصلية(المناخية) التي تحدث عنها تغيرات في درجتي الحرارة

والرطوبة.

ب-مجاورة المساكن للمستنقعات والبرك التي تتصاعد منها غازات فاسدة

تختلط بالهواء.

د/ محمود مهاي

(الأويئة وآثار ها في التراث العربي) 
ج- وجود المزابل ومياه الصرف الصحي وجثث الحيوانات النافقة بالقرب من الكساكن، والتي ينتج عن تحللها تصاعد غازات فاسدة تلوث الهواء. د- الفياضانات الكثيرة التي تحمل معها الحيوانات النافقة وجثث الغرقى عنى والمواد العضوية فتتسبب عنها أبخرة مشبعة بالغازات التي تلوث الهواء.

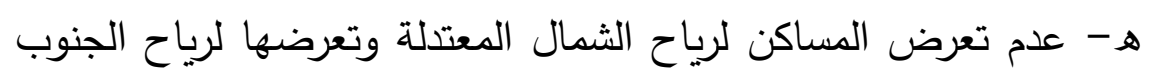
الحارة الرطبة التي تساعد على تكاثر الجراثيم (19). وبتأمل هذه الأسباب يتضح لنا أنها صحيحة بنسبة كبيرة؛ فالتغير الثنديد

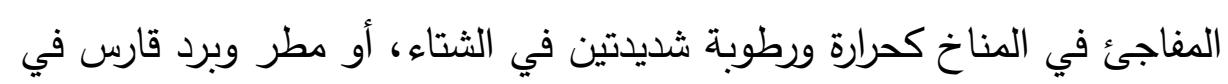

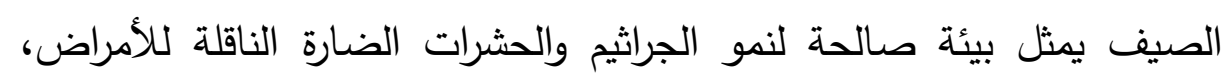

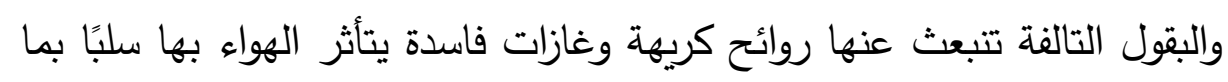
يحمله من روائحها الكريهة، وليس بخافٍ على أحد ما ينتج عن الزبول والأقذار

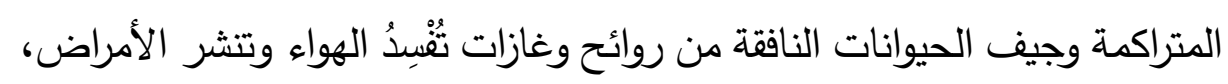

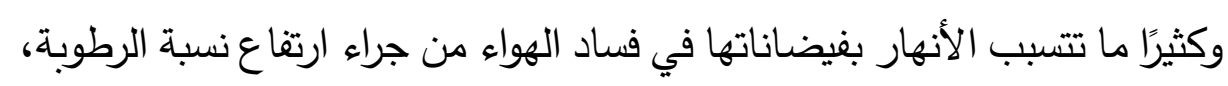

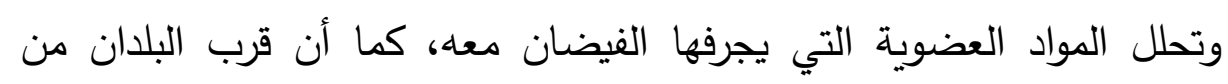

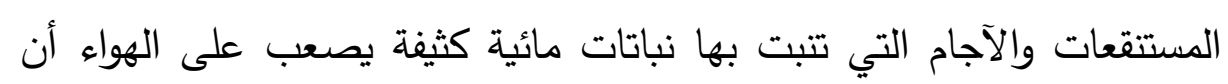

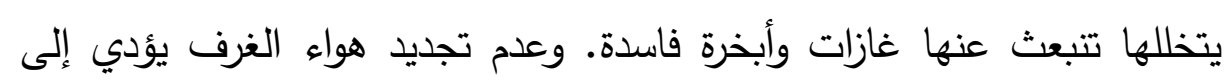

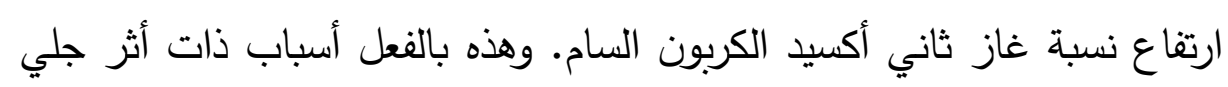
في فساد الهواء. 


\section{4-إصلاح الهواء الفاسد:}

رأى الأطباء أن هنالك مجموعة من التدابير العلاجية والوقائية الواجب اتباعها

عند حدوث الأوبئة العامة التي يساهم الهواء في انتشارها ونقلها، وأهم هذه التدابير :

$$
\text { * الحَجْرُ وعدم الاختلاط. }
$$

* إنثاء السراديبٍ اليابسةِ التي تُطَََّر بالخَلّ، ويطيب هواؤها بالبخور باللُّبَان وورقِ الآسِ والسُُعْد والصَّنْدَلِ والكَافُورِ .

* رشِّ الأماكنِ بالخِلاف والآسِ وماءِ الوردِ، ويجعل فيها الأنُزُْجُ. فبعدم اختلاط الأصحاء بالمصابين في الأماكن المغلقة يظل الهواء جيدا، أما إنشاء السراديب اليابسة الخالية من الرطوبة فلمنع تصاعد الأبخرة الرطبة التي تفسد الهواء، كما أن الخل اعتبر مطهرا ورشه يقضى على مابالسراديب من ملوثات الهواء كما زعموا، أما رشها بالخلاف والآس وغيره فلتطييب رائحة المكان، وفي كل ذلك بعض الصحة.

\section{5-الماء الحيد والماء الفاسد:}

إن الماء الصحي الجيد هو الماء الطبيعي الذي لم يتغير لونه ولا رائحته ولا

طعمه، وقد ضع الأطباء ضوابط عديدة تحدد نوعية المياه الجيدة المفيدة والمتمثلة في أن يكون لون الماء برَّاقًا صافيًا لم يخالطه مُكَِّّر . وأن يكون عديم الرائحة، طعمه عذبًا حلوًا، لا تشوبه كيفيةٌ أخرى. خفيفت الوزن. ويعرف وزنه بِبَلِّ خرقتين أو قطنتين متساويتي الوزن بماءين يراد معرفة وزنهما، ثم تجفَّفان تجفيفًا بالغًا، ثم توزنان، فالماء الخفيف تكون قطنته أخفَّ وزنًا. 
وهذه الطريقة فعالة حقا في معرفة الماء الصالح للاستعمال فالقطنة الأخف وزنا تشير إلى عدم اشتمالها على ما يعلق بالمياه من رواسب وشوائب وأملاح زائدة، والثتيلة بالعكس.

ومما يدل على خفته سرعة نضوبه وجفاف الأرض إذا شُقي منه؛ فإن الأرض

$$
\text { إذا سُقيت ماءً خفيفًا طيبًا عطشت أسرع(20). }
$$

وسرعة جفاف الأرض تدل على أن الماء لم تزدد كثافته بما تحلل فيه.

ورأوا أن أجود المياه ماء المطر القاطر وقت صفاء الجو، يليه ماء العيون

الثرقية، الحُرّة الأرض، التي لا يغلب على تربتها شيء من الأحوال والكيفيات الغربية، البعيد المنبع، الذي خرج بشدة من أودية على مقابلة الثمال، المنحدر من علٍ. المكثوف الذي يجري على الحصَى، ولم يمر ببطائح حتى لا يتلوث، متجهًا إلى الثرق أو الثمال ليقابل الثمس والهواء مدة طويلة، الذي يسخن سريعًا عند طلوع الثّمس عليه، ويبرد سريعًا عند غروبها عنه، وينحدر عن المعدة سريعًا بعد شربه، ويخفّف ثقل الطعام(21) ، ثم ماء الأرض الطينية التي لا حمأة فيها ولا سبخة(22) ، وهي أفضل من الحجرية؛ لأن الطين يُرَرِقُِ الماء وينقيه ويأخذ منه المززوجات الغربية، يليها ما كانت أرضه حجرية، ومياه الآبار والقنى بالقياس إلى يلى ماء العيون رديئة؛ لأنها مياه خالطت الأرض مدة طويلة فهي لا تخلو من تعفين ما. والماء النّز (23) أردأ من ماء البئر؛ لطول تردده في منافس الأرض المعفِّنة ويتحرك إلى النبوع، والمياه الراكدة والآجامية رديئة ثقيلة . 
وأدركوا أن هنالك عواملَ بيئية خارجيةً تؤثر في جودة الماء وتحيله للرداءة والفساد كطبيعة التربة، وحاله جريانًا وركودًا، وانكثافه واستتاره، ونقاء الهواء وتلوثه، يقول ابن سينا: إن المياه التي يخالطها جوهر معدني وما يجري مجراه، والمياه العلقية(24) كلها رديئة(25). ويؤكد ذلك ابن سهل البلخي(322هـ/934م) فيقول: إن المياه تتأثر بطبيعة منابعها فتكتسب كثيرا من خصائصها، فما تتبع من أرض طيبةٍ التربة عذبةٍ تخرج طيبةً عذبةً، وما تخرج من أرض مالحةٍ أو كبريتيةٍ وما أشبه ذلك من الطعوم، فإنها تقبل تلك الطعوم منها. كما أن الماء يتأثر بحال جريانه أو ركوده، كما يختلف الماء الظاهر على وجه الأرض عن الغائر في بطنها(26. ويقول ابن البيطار نقلا عن ديسقريدوس ( Discoides ت 60 م): تمييز الماء عسر لاختلاف الأماكن التي يكون فيها أو يمر بها واختلاف الهواء

\section{وأشياء أخر يتغير بها ليست بقليلة(27.). \\ 6-إصلاح الماء الفاسد :}

للماء الصحيح لذةٌ ودَخْلُ في تدبير الصحة إذا استعمل بشروطه التي رآها العلماء القدامى، وهي: ألا يؤخذ قبل الهضم، ألا يستعمل الفاسد منه بلا مصلح، ورأوا أن إصلاح الماء الفاسد يكون بطبخه(28) في آنية بحطب الطرفاء(29) ، لأن حطب الطرفاء ودخانه لهما خاصية في إصلاح الهواء والماء الفاسدين، ويطبخ الماء حتى يذهب منه الربع، ثم يرد في آنية مصنوعة من الخزف الرقيق المتخلخل الأجزاء، الكثير الرشح، ويلقى فيه حال تبريده الطين الأرمني والطين الرومي

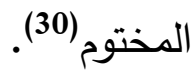


وطريقة تصفية الماء الكدر : إن كانت العوالق كالأتربة يلقى فيه اليسير من الثبّ الأبيض اليماني، أو يلقى فيه شيء من لُبّ نوى المشمش، أو قلوب اللوز

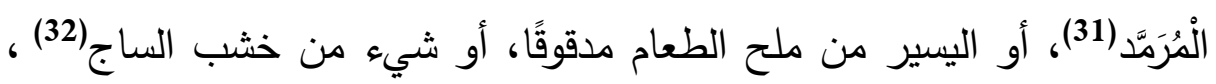
فإلقاء أحدها في الماء ثم تحريكه جيدًا وتركه فترة زمنية يصفيه ويروِقهه ويفصل العنصر الأرضي منه بسرعة(33).

كما يَصلح الماء الفاسد بالتقطير الذي يعيد الرديء جيدًا لفصله المادة الكثيفة

عنده .

ومن الطرق الطريفة التي ذكرها ابن سينا: فتل فتيلة من صوف، وجعل أحد طرفيها في الإناء الملوه بالماء المراد إصلاحه، والطرف الآخر في إناء خال، فتمتص الفتيلة الماء ثم تقطره مروقا في الإناء الخالي(34). ومن اضطر إلى شرب الماء العفن فليمزجه برُبُوب الفواكه الحامضة، كرُبِّ

الرُّمَّان والحِصْرِمِ والرِِّيَّاس (35). وقد يُعالج الماء المالح ليعذب؛ بأن يصعَََّ بأنبيق وقَزْعِ(36) كما يفعل بالورد. أو يوضع فيه إناءٌ كالأقداحِ من شَمْعْ؛ فإنها يرشح إليه من خارجه ماء عذب، أو يخلط بطينٍ جيدًا، أو يخلط بسويقِ في جِرَارٍ جددٍ، ويُسْنَتْطَرُ (37). وواضح أن كثيرًا من طرق تنقية المياه كالترشيح والتقطير لا تزال صالحة الاستخدام والاستعمال حتى يومنا هذا.

\section{7-أسباب أخرى لحدوث الوباء وانتشاره:}

لقد كان التميمي(38) بارعًا مبدعًا حين تحدث عن كيفية الإصابة بالأمراض عند استنشاق الهواء الملوث، فيقول:"فيتحصل باستنشاقه في أجسام ساكني هذه 
الدن خمائر أمراض خالطت أخلاطهم الغالية ومازجتها، فأحدثت فيها أعفانًا تتمو شينًا فثينًا، فإذا انصرم فصل القيظ ودخل فصل الخريف أثمرت تلك الخمائر

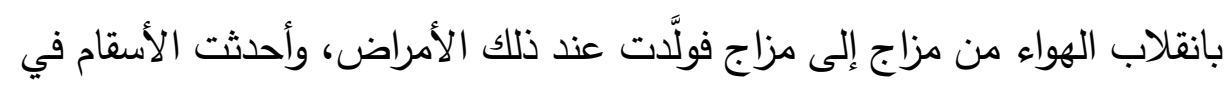

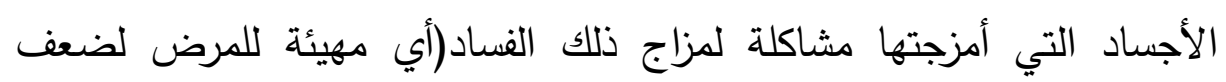
مناعتها)، وهي التي كانت في الفصل المتقدم متهيئة لقبول تلك الخمائر التي لـاجي حصلت في أخلاطها فعفنتها وأحالتها مرضا (39) ". ويعلق السيد يحيى شعَار محقق كتاب التميمي"مادة البقاء في إصلاح فساد الهواء، والتحرز من ضرر الوباء" على هذه الرأي مفسرًا المراد بقوله"خمائر" فيقول:

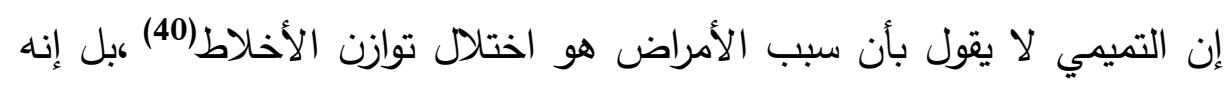

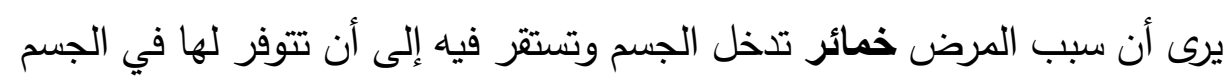

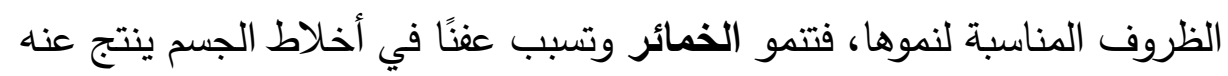

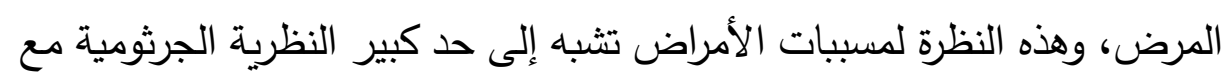
الاختلاف في تسمية الجراثيم بالخمائر (41).

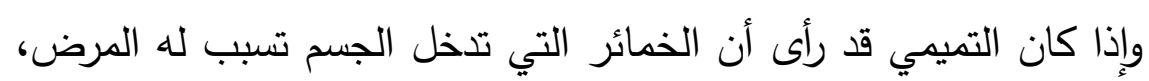
فإننا نرى طبييًا عربيًا مخضرمًا يشير إلى مخاطر البعوض كسبب في حدوث

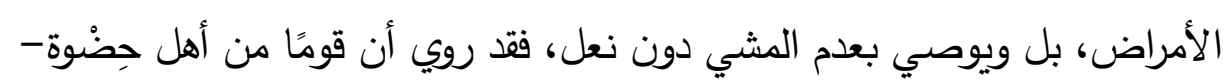

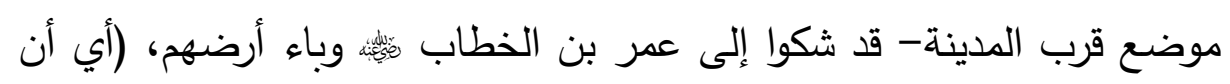
ساكنيها كثيرو الأمراض). فقال لهم : لو تركتموها! فقالوا: فيها معاشنا ومعاش إبلنا، ووطننا. فقال عمر للحارث بن كلدة: ما عندك؟(أي ما تفسيرك لهذا الأمر ) 
فقال الحارث: البلاد الوبئة ذات الأدغاد والبعوض وهو عش الوباء، ولكن ليخرج أهلها إلى ما يقاربها من الأرض العذبة، وليأكلوا البصل والكراث، وليمسكوا الطيب، ولا يمشوا حفاة(42).

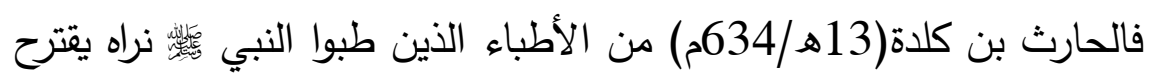
على أهل هذه البلدة التي كانت تقع بجوار جدول ماء تتبت فيه نباتات كثيرة كالبوص وغيره، يجد البعوض فيها بيئة مناسبة للتكاثر ومن ثَ مهاجمة الناس، يقترح عليهح الابتعاد عنها لأنها بيئة ملوثة مسببة للأمراض، وإشارته إلى البعوض تفيد إدراكه لمخاطره، ويأمرهم بتناول البصل والكراث لمقاومة المرض، ولهذين فوائد جمة في قتل جراثيم الفم، كما يوصيهح بعدم مشيهم حفاة، ومعلوم أن التربة الملوثة يمكن أن تتنقل منها الأمراض إلى الناس. وإذا كنا اليوم نركز في تحذيراتتا من الوباء بضرورة التباعد الاجتماعي، وتقليل التجمع في الأماكن الضيقة أو المغلقة، وعدم استعمال أدوات المريض حتى لا ينتقل المرض من مصاب إلى صحيح فإن التميمي قد فطن إلى ما يشبه ذلك، فنراه يقول:"وذلك لأجل أن الهواء يحمل رائحة الفساد الذي يظهر من جسد العليل وينفصل عنه بالتنفس فيؤديه إلى الصحيح المجاور، إنما هو بكثرة نفس العليل، فإذا استنشق ذلك النفس الفاسد المنفصل من نفس العليل من الأصحاء الذين يأوون إليه ويقربون منه فسدت أبدانهم، وغلبت العفونة عليهم فأمرضتهم(43). ويدلل التميمي على صحة نظريته بأن المنزل الذي فيه جماعة لم يصابوا بالحصبة أو الجدري إذا أصيب أحدهم بأي من هذين المرضين لم يمر وقت طويل 
حتى تنال الإصابة الباقين، والسبب في ذلك استنشاقه للهواء الملوث بأنفاس المريض.

ثم يقول:" وقد نجد كثيرًا من العلل تعدي من دنا من العليل مباشرة أو باشره أو واكله(أكل معه من إناء واحد)، أو شرب من إنائه الذي يثرب فيه، أو ضاجعه

$$
\text { في فراشه(نام معده في سرير واحد) (44). }
$$

كما لاحظ العلماء أن انتقال الناس من الأماكن الموبوءة إلى البلدان الصحيحة يصيب أهلها بالوباء لحمهم الوباء وإن كانت آثاره لم تبدُ عليهم، وقد حدث أن انتقل الطاعون إلى المغرب مع التجار القادمين إليها، ومع الجند العائدين من الحروب في الأراضي الموبوءة إلى مواطنهم الأصلية(45).

\section{8-الأوبئة في كتب التاربخ:}

ليس التاريخ كالأدب تمامًا، فالأول يرصد الأحداث والإنجازات والوقائع التي عاشتها المجتمعات كما هي -غالبا- ويسجها كيفما وقعت، لا مجال فيه للأخيلة، لأنه يتعامل -في الغالب- مع الحقائق، أما الأدب فيجمع بين الحقيقة والخيال،

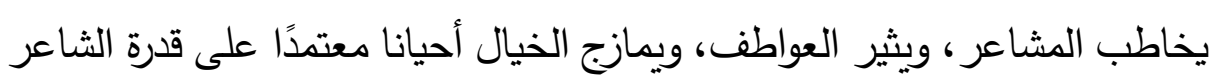
وتمكنه من اللغة وأدواتها. ومع ذلك فقد نجد في كليهما ما يشبه الآخر . لذا فتتاول كتب التاريخ للأوبئة هو تسجيل لها زمانا ومكانا ومظاهر ونتيجة، ومن خلال استقراء بعض كتب التاريخ التي عاصر مؤلفوها بعض هذه الأوبئة، وسجلوا ما شاهدوه وما سمعوه يمكن رصد بعض الآثار الاجتماعية والاقتصادية. 
وفي هذه العجالة سأقتصر على عدة أخبار للأوبئة من كتاب "السلوك لمعرفة دول الملوك" محاولا استخلاص بعض الآثار الاجتماعية والاقتصادية والأدبية منها: يقول المقريزي(845هـ/1441م): في هذه السنة تزايد الوباء بحيث كان يخرج من كل باب من أبواب القاهرة في كل يوم ما يزيد على سبعمائة ميت...ثم تزايد الأمر فصارت الأموات تدفن بغير غسل ولا كفن، فإنه يدفن الواحد في ثوب ثم

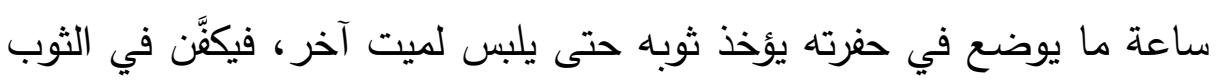
الواحد عدة أموات. وعجز الناس عن مواراة الأموات في القبور لكثرتهم وقلة من يحفر لهم، فعملت حفائر كبار ألقيت فيها الأموات من الرجال والنساء والصبيان حتى تمتلى الحفرة، ثم تطم بالتراب. وانتدب أناس لحمل الأموات ورميهم في الحفر، فكانوا يأخذون عن كل ميت نصف درهم، فيحمله الواحد منهم ويلقيه إما في حفرة أو في النيل إن كان قريباً منه. ومات كثير من الناس بأطراف البلاد فبقي على الطرقات حتى أكلته الكلاب، وأكل كثيرًا منها بنو آدم أيضًا، وحصر في شهر واحد من هذه السنة عدة من مات ممن قدر على معرفته، فبلغت العدة مائة ألف وسبعة وعشرين ألف إنسان. وفي سنة 749 هـ /438م كان فيها الوباء الذي لم يعهد في الإسلام مثله، فقد كان يموت بالقاهرة ومصر ما بين عشرة آلاف إلى خمسة عشر ألف إلى عشرين ألف نفس في كل يوم. وعملت الناس التوابيت والدكك لتغسيل الموتى للسبيل بغير أُجره، وحمل أكثر الموتى على ألواح الخشب وعلى السلالم والأبواب، 
وحفرت الحفائر وألقوا فيها. وكانت الحفرة يدفن فيها الثلاثون والأربعون، وأكثر. وكان الميت بالطاعون يبصق دمًا، ثم يصيح ويموت؛ وعم مع ذلك الغلاء الدنيا جميعها. كما عم الوباء بلاد الفرنج، وابتدأ في الدواب، ثم الأطفال والثباب. فلما شنع الموت فيهم جمع أهل قبرص من في أيديهم من الأسرى المسلمين، وقتلوهم جميعاً من بعد العصر إلى المغرب، خوفا أن يبيد الموت الفرنج، فتملك المسلمون قبرص. وعم الوباء جميع الأراضي، ومات الفلاحون بأسرهم، فلم يوجد من يضم الزرع، وتعطلت بساتين دمياط وسواقيها، وجفت أشجارها، لكثرة موت أهلها ودوابهج، وصارت حوانيتها مفتحة والمعايش بها لا يقربها أحد، وغلقت دورها. وبقيت المراكب في البحيرة، وقد مات الصيادون فيها والثبالك بأيديهم مملوءة سمكاً ميتاً،ولم يحتج أحد في هذا الوباء إلى أشربة ولا أدوية ولا أطباء، لسرعة الموت. فما تتصف شوال إلا والطرقات والأسوق قد امتلأت بالأموات، وهلك أكثر أجناد الحلقة؛ وخلت أطباق القعة من المماليك السلطانية لموتهج. ث كان الحال كذلك بأراضي مصر ، فما جاء أوان الحصاد حتى فني الفلاحون، ولم يبقى منهم إلا القليل فخرج الأجناد وغلمانهم لتحصد، ونادوا من يحصد ويأخذ نصف ما يحصده. فلم يجدوا من يساعدهم على ضم الزروع، ودرسوا غلالهم على خيولهم، وذروها بأيديهم؛ وعجزوا عن كثير من الزرع، فتركوه. فلما كان أيام النيل، وجاء أوان التخضير (أي الزرع) تعذر وجود الرجال، فلم يخضَّر إلا نصف الأراضي. وتركت ألف وخمسمائة فدان براسيم بناحية ناي وطنان، فلم يوجد من يثتريها لرعي دوابه، ولا من يعملها دريسا. وعطلت أكثر 
الصنائع، وانحط سعر القماش ونحوه، حتى بيع بخمس ثمنه وأقل و لم يوجد من

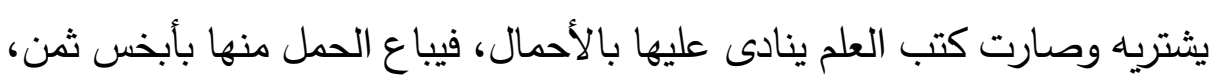

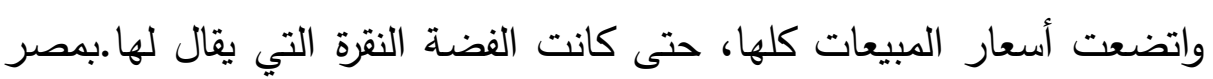

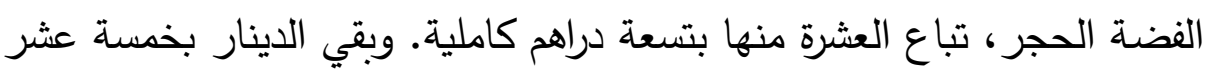
درهما، بعدما كان بعشرين. وبطلت الأفراح والأعراس من بين الناس، وتعطل الأذان من عدة مواضع، بعان وبقي في الموضع المشهور بأذان واحد. وعدمت جميع الصنائع، فلم يوجد سقاء، وبلغ ثمن راوية الماء إلى ثمانية

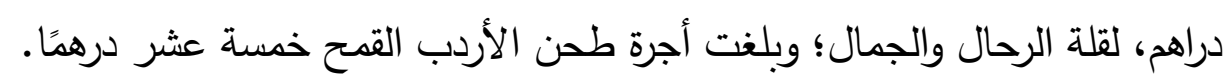

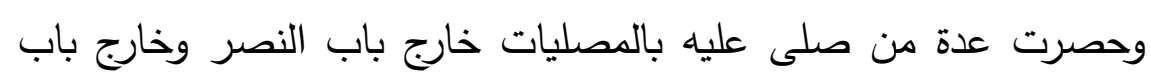

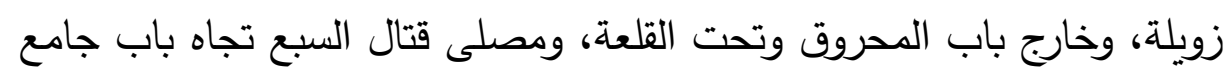
قوصون، في يومين، فبلغت ثلاثة عثر ألفا وثمانمائة، سوى من مات في في الأسواق

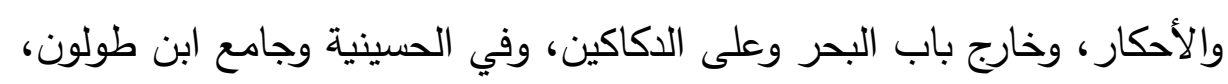

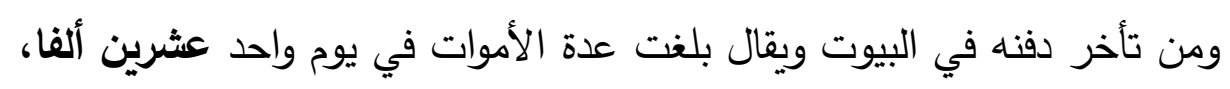

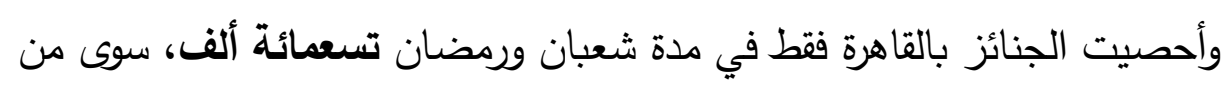

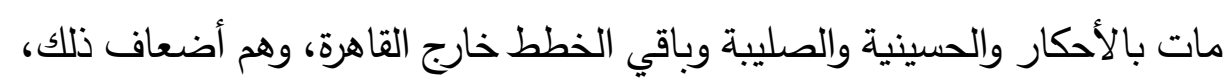
وغلتت أكثر المساجد والزوايا(46).

إن قراءة ما سطره المقريزي وغيره عن الأوبئة لأمر مهول يبرز حجم النازلة على كافة المستويات الاجتماعية والاقتصادية، ومن أهم آثارها. 


\section{أولا: الآثار الاجتماعية:}

فقدان القوى البشرية المنتجة، فتعطلت الزراعة والصناعة، وغيرها من الحرف ؛ مما أدى إلى أزمات اقتصادية خطيرة.

انتشار الفقر، فزادت نسبة الطبقة الفقيرة، وتحول كثير من الطبقتين الوسطى والثرية إلى الطبقة الأدنى. انهيار القيم والأخلاق الكريمة عند كثير من الناس، متبعين مبدأ الغاية تبرر الوسيلة.

انعدام الأمن الاجتماعي، فكثرت حوادثُ السلب والنهب والسرقة والسطو ، والاعتداء على النساء في الثوارع. ظهور الثراء على بعض الفئات نتيجة استغلالهم حاجة الناس لخدماتهم أو سلعهم، كبعض الأطباء وباعة الأعشاب الطبية وتجار المواد الغذائية. فزادت أرباح بعض الأطباء والعشابين، وباعة السلع الغذائية، لكثرة الإقبال والطلب، ففي أزمة عام (694 - 695هـ/ 1294 - 1295م) بلغت مبيعات أحد العطارين في شهر واحد برأس حارة الديلم اثثين وثلاثين ألف درهم. أما التجار ، فقد أصاب أحدهم ربحاً ما بين 100 - 200 درهم في اليوم، بينما السوقة بلغ ربحهم ثلاثين درهماً.

نزول الجند للعمل بفلاحة الأرض مما أثر في تركيبة المجتمع المصري. هجرة الكثير من الناس من بلادهم إلى بلاد أخرى لم تظهر بها الأوبئة. تفثي ظاهرة التسول.

د/ محمود مهدي

(الأوبئة وآثار ها في التراث العربي) 
كثرة تصارع عامة الناس وتشاجرهم واقتتالهم من أجل الحصول على

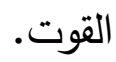

ولعل من أخطر الآثار الاجتماعية زيادة عدد الرقيق بثكل ملحوظ نتيجة

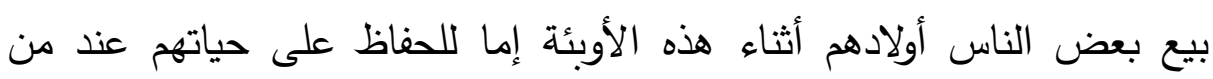

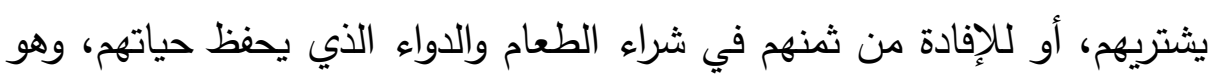

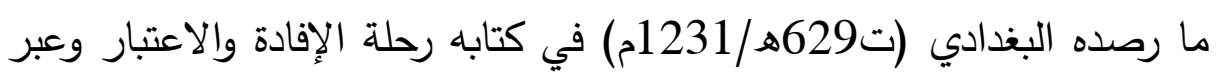
عنه بقوله:" أما بيع الأحرار فثاع وذاع". اللجوء إلى الله والتضرع والتقرب إليه بكثرة الدعاء وقراءة القرآن والدكوث في المساجد لرفع الغمة وكثف الكرب.

\section{ثانيا:الآثار الاقتصادية:}

تعطل مهنتي الفلاحة والصيد نتيجة موت كثير من الفلاحين والصيادين. قلة الإنتاج الزراعي وتدهور المحاصيل الزراعية نتيجة عدم الزرع وجني مني لعين

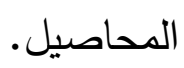

فقدان الثروة الحيوانية نتيجة إصابتها بالوباء، وعدم وجود من يرعاها.

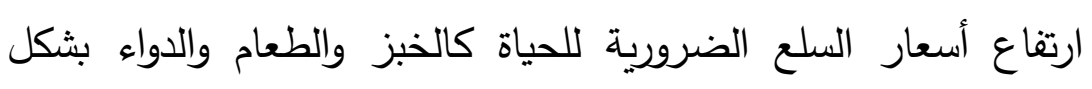
مضطرد يعجز عنه الفقراء. انخفاض سعر العملة، وزيادة نسبة التضخم نتيجة وفرة المال وندرة السلع. بَور الأراضي الزراعية نتيجة نقص اليد الفالحة. 
تدهور الصناعة؛ وقد أشار البغدادي إلى أنه كان ابمصر 900 مَنْسَج للحصر ، ولم يبق منها إلا خمسة عشر منسجاً، وقس على هذا مِن باعةٍة، وخبازين، وعطارين، وأساكفة، وغير ذلكه.

أدى تعطل الصنائع إلى استتزاف رصيد البلاد من الذهب، والفضة، نتيجة تعويض النقص المحلي بالاستيراد. 9-الأوبئة في الأدب:

لم يفوت الأدباء فرصة هذه الأحداث الجسام التي تحط بثقلها وآلامها على صدور الناس فلا يستطيعون معها قيامًا، وأدب النكبات والمصائب -في غالبهمن أصدق ما ينظم ويكتب؛ لأن التجربة فيه غاللًا ما تكون صادقة، والثعور فيها كثيرًا ما يكون ذاتيا، فهل يمكن لأب فقد أولاده أن يقول غير ما يشعر به، أو لمريض يترصده الموت أن يصف غير الحقيقة، وهدفنا هنا رصد بعض المشاعر والأحوال التي عاشها الناس في زمن الوباء، ولم يفوت الأدب تسجيلها. وقد جاء أكثر من فن من فنون الأدب مصورا هذه الأحوال، ومنها. أ-الشعر:

\section{أبو ذؤبب الهذلي (47) يرثي أولاده:}

ها هو أبو ذؤيب الهذلي أب يرى أمام عينيه الوباء يحصد أرواح أولاده الخمسة وهم في عنفوان شبابهم وزهرة حياتهم، وهم من كانوا يعوّل عليهم في شيخوخته قد فارقوه وتركوا له الحسرة والألم واللوعة، وشحوب اللون، وقلق المضجع، والذمع الذي لا ينقطع، ومع بكائه الدائم يظهر التجلد والصبر حتى لا 
يشمت به الثامتون. فينظم في رثائهم قصيدة من أجمل ما نُظم في الرثاء، وفيها يقول:

بعد الرُّقادِ، وعَبرةً مَا تُقِّعُ

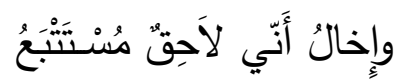

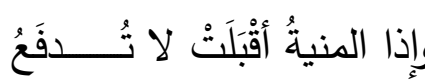

أني لريبٍ الدهر لا أتضعضحُ(48)

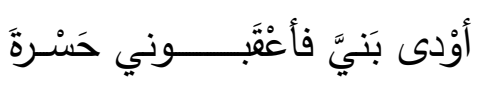

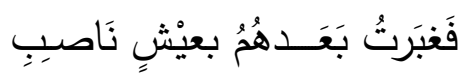

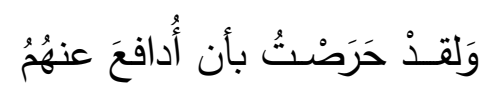
وفيها يقول:

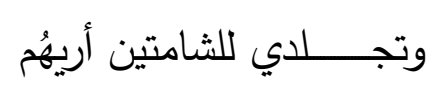

ولصلاح خليل بن أيبك الصفدي أبيات شعرية يتناول فيها الطاعون من جوانب عدة:

حيث يصور سرعة نزول البلاء الذي يشغل كل امرئ بنفسه، حتى يذهل الوالد عن ولده، مشبهًا الناس الذين يحصد الطاعون أرواحهم في لحظة واحدة بالثمعة المتقدة التي يطفئها الطاعون بنفخة واحدة منه فيقول: قد نغص الطاعون عيش الورى وأذهل الوالد والوالده كـــم منزل كالشمع سكانُهـ أطفأهم في نفخة واحده ويخاطب عام 749 هـ الذي افترس طاعونه أصحابه مستخدمًا أسلوب التورية بأنه ليس تسعًا، بل سبعًا، و"سبعا" ليس المراد به العدد، إنما المراد بالسبع الأسد المفترس.

$$
\begin{aligned}
& \text { لما افترست صحابي يا عام تسِ وأربعينا } \\
& \text { ما كنت والله تسعًا بل كنت سبعًا يقينا }
\end{aligned}
$$

ويرصد بعض أعراض الوباء كتورم الغدد الواقعة تحت الإبط، ونفث الدم، فيقول.

د/ محمود مهدي

(الأويئة وآثار ها في التراث العربي) 
رعى الرحمن دهـرا قد تولى يحاذي بالسلامة كل شـرط

وكان الناس في غفلات أمـر فجا طاعونهم من تحت إبط

وقال:

يا رحمتا لامشق من طاعـــونها فالكل مغتبق به أو مصطبح

كم هالك نفث الدما من حلقه أو ما تراه بغير سكين ذُبح(49)

وقال الأديب بلر الدين الحسن بن حبيب الحلبي يصف بعض آثار الوباء:

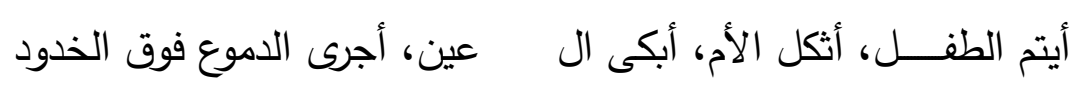

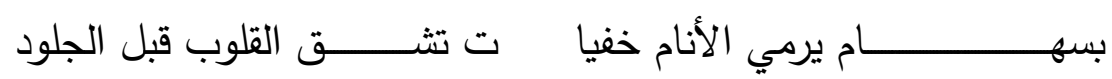

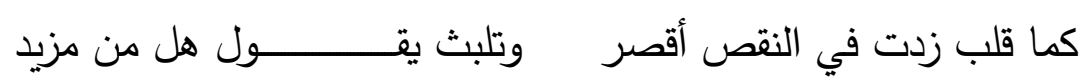

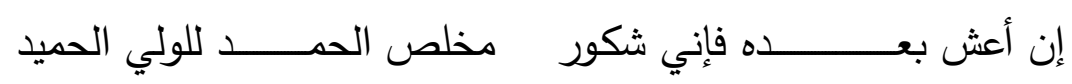

وإذا مت هنئـــوني وقولوا مم قتيل كما قتلت شهيد (50)

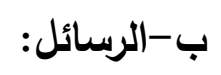

ينقل ابن حجر العسقلاني في كتابه بذل الماعون رسالة كتبها القاضي صلاح الدين خليل بن أيبك الصفدي في تذكرته يصف فيها ما يفعله الطاعون بالعباد، فقد صار به الجبابرة جبناء خائفون(وأصبح كل جبار وهو منه خائف، ويظن أن الموت على بابه واقف)، والناس لا يتألمون كثيرًا على فراق أحبتهم لأنهم ينتظرون مصيرهم(غير أن له خلائق محمودة، وغرائب ليست في سواه موجودة، لا يفرق بين الشخص وأقاربه، ولا يؤرق جفن المفجوع على ذاهبه، بلإن أخذ واحدا آنسه بجميع أهله) وفي النوازل يكثر التضرع والاستغاثة بالقادر على رفع ما أنزل(فاله الله في التضرع بارتفاع هذه النازلة، وانقطاع هذه النقمة برحمة متواصلة) (51). 


\section{ج- المقامة:}

المقامة فن أدبي يجمع أحيانًا بين النثر والثعر ، والفكاهة والسخرية بهدف الترويح عن الناس وتخفيف آلامهم، وللثيخ ابن الوردي(52) مقامة رائعة في الطاعون وعمومه وتفشيه، وتتبع مساره، وتعد هذه المقامة أتم ما سجله الأدباء عن الطاعون انتشارًا ومظاهر ترقبه والخوف منه، ومشاعر الناس قبيل مغادرتهح للحياة، ومحاولاته إصلاح ما أفسدوه في حياتهم علها تكون خير ختام لحياتهم مستخدما في ذلك العديد من ألوان البديع كالسجع والجناس والتوية والاقتباس. وابن الوردي في مقامته يسْخر من الطاعون، ومن الفئة القليلة المستغلة لآلام

الناس، وممن غيَّر خوفهم من الطاعون سلوكياتهم، وفيها يقول: " الله عُدة في كل شدة، حسبي الله وحده، أليس الله بكاف عبده، اللهم صلِّ على سيدنا محمد وسلم، ونجنا بجاهه من طغيان الطاعون وسلم، طاعون روَّع وأمات، وابتدأ خبره من الظلمات، يا له من زائر!، ما صين عنه الصين، ولا منع منه حصن حصين، سل هنديا في الهند، وأسند على السند، وقبض بكفه وشبك، على بلاد أزبك، وكم قصم من ظهر ، فيما وراء النهر، ثم ارتفع ونجم، وهجم على العجم، وجر الجرائر إلى قبرص والجزائر، ثم قهر خلقا بالقاهرة، وتتبهت عينه بمصر فإذا هم بالساهرة، وسكَّن حركة الإسكندرية... ثم تيمم الصعيد الطيب، وأبرق على برقة منه صيب، ثم غزا غزة..." فقد ذكر فيما سبق عددا كبيرا من

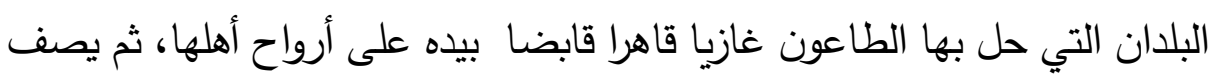
آثاره راصدا عرضا من أعراض الوباء وهو قيء الدم، وكيف أنه بعد ظهور هذا العرض بليلة أو ليلتين يسلم المصاب روحه لبارئها، فيقول: "ومن الأقدار أنه يتتبع 
أهل الدار، فمتى بصق واحد منهم دما، تحقق كل واحد منهم عدما، ثم يسكن

$$
\text { الباصق الأجداث بعد ليلتين أوثلاث. }
$$

سألت بارئ النسم في دفع طاعون صدم

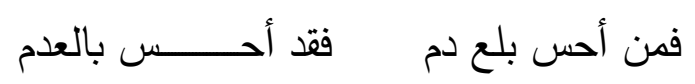

ثم يسجل مظهرًا يجسد حال المنتفعين بالنوازل، المستقيدين من المصائب،

وهذه فئة لا يخلو منها زمان ولا مكان، تراهم وقد تبلدت حواسهم، وكأن الرحمة قد نزعت من قلوبهم، فلا همَّ لهم إلا تحصيل المال ولو على آلام الناس، لذا فهو

يدعو عليهم، يقول:

"ولقد كثرت فيها أرزاق الجنائزية فلا رزقوا، وعاشوا بهذا الموسم وعرقوا فلا

عاشوا ولا عرقوا، فهم يلهون ويلعبون، ويتقاعدون على الزبون".

ثم يقول ساخرًا: "إن للطاعون فوائد، منها تقصير الآمال، وتحسين الأعمال، واليقظة من الغفلة، والتزود للرحلة.

فهذا يوصي بأولاده وهذا يودع إخوانه

وهذا يهيء أشغاله و وهذا يجهز أكفانه

وهذا يصالح أعداءه وهذا يرطف جيرانه

وهذا يوسع إنفاقه وهذا يحلل من خانه

وهذا يحبس أملاكه وهذا يحرر غلمانه

وهذا يغير أخلاقه وهذا يعير ميزانه(53) 
ومن عجب أن ابن الوردي ختمت حياته بالطاعون بعد يومين من نظمه أخر بيتين له من الشعر يسخر فيهما من الطاعون، ويعلن عدم خوفه منه، بل واستعداده لقدَرِه، وكأنه يرثي نفسه، فيقول: ولست أخاف طاعـــونا كغيري فما هو إلا إحـــــى الحسنيين فإن مت استرحت من الأعادي وإن عشت اشتقت أذني وعيني(54)

لابد من الإثارة إلى أن حوادث الماضي وتجاربه التي سجلها العلماء في كتبهم الطبية والتاريخية والأدبية تثبه إلى حد ليس بالقليل مما هو كائن في الحاضر ، ويمكن أن يتكرر في المستقبل، فكما يقال"التاريخ يعيد نفسه" ودراسة هذه الكتب واستخلاص الأسباب والمظاهر والنتائج تساهم بشكل كبير في وقاية الحاضر ، بل والمستقبل مما حل بالسابقين. ونستطيع أن نخلص من هذا البحث إلى نتائج منها: 1-تحفل كتب التراث العربي في العديد من فنونه بما يستحق الدراسة والوقوف على ما به مما يؤكد مساهمة الحضارة العربية في النهضة الإنسانية، وبما يمثل جذورًا راسخة للكثير مما ثبت حديثًا صحته في العديد من المجالات. 2- وقف علماؤنا على العديد من أسباب الأمراض والأوبئة كتلوث الهواء والماء، والجراثيم، ومخالطة المرضى، والحشرات الضارة، وغيرها. 3- الوباء لا حدود لانتشاره، فإذا حل عم، وبالتالي فيجب التكاتف والتكافل والتعاون للحد منه ومن آثاره. 
4- عُني العلماء بسلامة البيئة، ووضع الضوابط التي يجب على الناس

اتباعها، وتكليف من يتابع تتفيذها، ومعاقبة المخالفين لها.

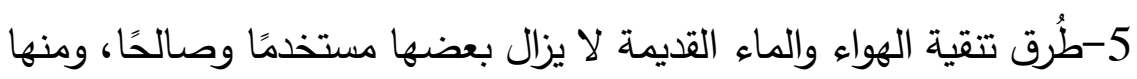

الترويق، الغلي، التقطير ·

6- رصدت لنا كتب التاريخ الكثير من الآثار السلبية للأوبئة اجتماعية كانت

أو اقتصادية، ككثرة الوفيات، وارتفاع نسبة الفقر، واستغلال الأزمات للتربح، وتعطل كثير من المهن، وقلة الإنتاج، وارتفاع الأسعار ، وهي آثار يعيشها كثير من المجتمعات الموبوءة حديثًا.

7- يسجل الأدب من خلال بعض فنونه مشاعر الناس وآلامهم نحو الوباء، وما يحدثه فيهم من آثار جراء فراق الأهل والأحبة، وتصويره بالصور التي تبرزه في صورة غير محبوبة.

وأخيرا فإن التراث العربي لا يزال بحاجة إلى دراسات شاملة متأنية منصفة

تضعه في موضعه اللائق به كعامل فاعل في الحضارة الإنسانية، وتقدر جهود علمائه ودورهم في تطور العلوم، والإفادة مما به من أفكار صالحة للبناء عليها حاضرًا ومستقبلا.

\section{***}

د/ محمود مهاي

(الأوبئة وآثار ها في التراث العربي) 


\section{المصادر والحواشي:}

1 - القاموس المحيط: مجد الدين محمد بن يعقوب الفيروز آبادي، ترتيب خليل مأمون شيحا، دار المعرفة، الطبعة الثالثة، 2008/1429: (وبأ) 1376. 2- كثاف اصطلاحات الفنون: محمد علي التهانوي، تحقيق: د ـ ـ علي دحروج، مكتبة لبنان، الطبعة الأولى، 1753/1996:2

3- العين: الخليل بن أحمد الفراهيدي، تحقيق: د ـ ـ عبد الحميد هنداوي، دار الكتب العلمية، الطبعة الأولى، 1424/2003: (وبأ) 343/4. 4 - بذل الماعون في فضل الطاعون: أحمد بن علي بن حجر العسقلاني، تحقيق: أبو إبراهيم كيلاني، دار الكتب الأثرية، الطبعة الأولى، 1993/1413: 44. 5-الجامع المسند الصحيح(صحيح البخاري): محمد ابن إسماعيل البخاري، دار ابن كثير للنشر التر

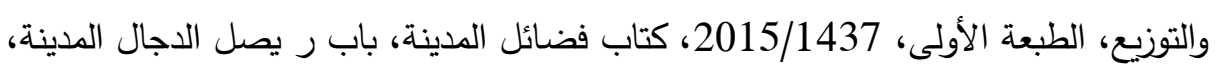
رقم(1889):339.

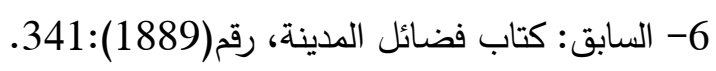
7-بذل الماعون:45. 8 - منخفضة عن وجه الأرض. 9 -البطائح: ج بطيحة، وهي مكان متسع به حصى وتراب لين جرته السهول إليه. 10- الثيج: هو ما اختلط بما يغير طبيعته. 11 - الكوى: ج كوة، وهي فتحات تعمل في الحوائط بقصد التهوية والإضاءة. 12- القانون في الطب: ابن سينا، تحقيق: إدوار القش، مؤسسة عز الدين للطباعة والنشر، بيروت، 98/1987:1/1408.

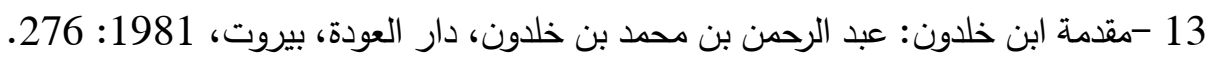
14- عيون الأنباء في طبقات الأطباء: ابن أبي أصيبعة، تحقيق: د ـ ـ عامر النجار، الكيئة المصرية العامة للكتاب:13/2. - ماكئ 
15- الميازيب: ج ميزاب، وهو قناة أو ماسورة عموديّة يجري فيها الماء منصرفًا من أسطح الأدور أو المواضع العالية، فينسكب على الأرض بعيدًا عن جدرانها. 16 -نهاية الرتبة في طلب الحسبة: عبد الرحمن بن نصر الثيرازي، تعليق السيد الباز العريني، مطبعة لجنة التأليف والترجمة والنشر، القاهرة، 1946/1365: 22-25. 17 -مادة البقاء: 120.

18- القانون: ابن سينا، دار إحياء التراث العربي، بيروت، الطبعة الأولى، 2005/1426: $.118 / 1$ 19-السابق:122/1.

20 - منهاج البيان في ما يستعمله الإنسان : ابن جزلة ، تحقيق د ـ محمود مهدي ، معهد المخطوطات العربية ، 2010: 812 . 21 - المنصوري في الطب: الرازي، تحقيق : د . حازم البكري، معهد المخطوطات العربية، الكويت، 1987/1408 : 127 . 22- منهاج البيان: 763 . 23 - الحمأة : الطين الأسود المنتن • والسبخة : ذات الملح والنز • 24 - النز : ما تحلب من الأرض من ماء . 25- المياه العلقية هي مياه تولد بها دود كالعلق يتجرع مع الماء أثناء الثرب فيصيب الإنسان بالعديد من الأمراض.

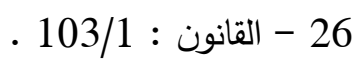

27 - مصالح الأبدان والأنفس : البلخي، تحقيق : د. محمود المصري، معهد المخطوطات العربية، القاهرة ، 2005: 352 . 28 - الجامع لمفردات الأدوية والأغذية: ابن البيطار، دار الكتب العلمية، بيروت ، ط : الأولى، 1992/1412 : 407/4.

29 - المراد بالطبخ الغليان ..

د/ محمود مهاي

(الأوبئة و آثار ها في التراث العربي) 
30 - الطرفاء : بالمد واحدته طرفاءة وطرفة، وهي شجرة تتبت عند المياه القائمة ، ولها ثمر

شبيه بالزهر ، وثمرها يسمى جِْْمِج • ينظر : الجامع : 3 / 132.

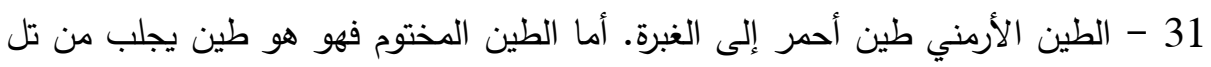

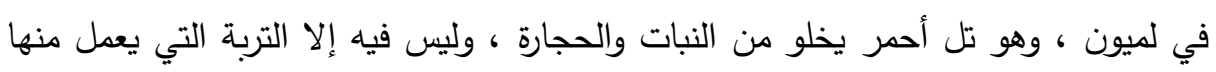

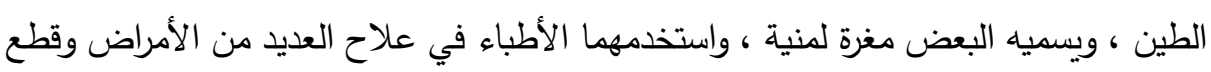
الزف شربا وطلاء. ينظر : منهاج البيان :594، 596 .

$$
\text { 33- 32-القانون:242/1. }
$$

34 - هو نوع من الثجر الضخم ، خشبه أسود صلب يسمو كثيرا، وفروعه طويلة ذات أوراق كثيرة، يستعمل طبيا في مداواة العديد من الأمراض كتحليل الأورام الصفراوية والدموية، ونشارة

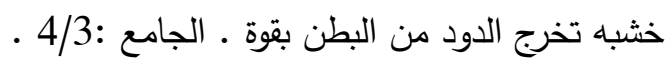
35- مادة البقاء : التميمي الدقدسي، تحقيق : يحيى الثعار، معهد المخطوطات العربية،

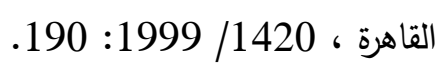
36 37 - إناءان موصولان بأنبوب يستعملان في التصعيد، يحوي أحدها السائل وبغليانه يصعد

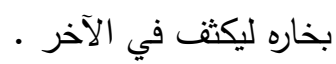
38- الحصرم : هو غض العنب ما دام أخضر، وهو في الكرم بمنزلة البلح في النخل .

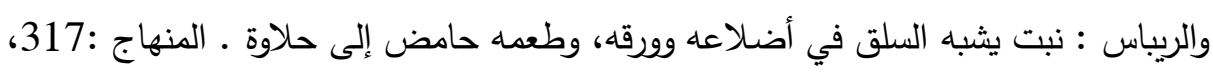
438 766

39 - .هو أبو عبد الله محمد بن أحمد بن سعيد التميمي المقدي، أقام أولا بالقد، وبها قرأ علم الطب وغيره، وبها تتلمذ على الحسن أبي محمد بن نعيم، وتميز في الطب وتركيب الأدوية، حضر إلى مصر ولقي أطباءها وناظرهم، من أعماله:مادة البقاء بإصلاح فهاد الهواء، توفي

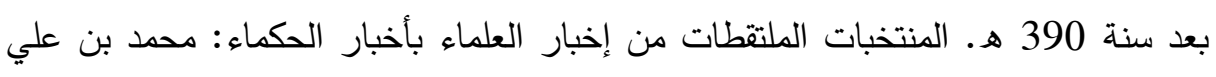


الزوزني، تحقيق:د ـ محمود مهدي، جامعة مصر للعلوم والتكنولوجيا، الطبعة الأولى، 2103: .218

40 - مادة البقاء:132.

41 - هذا رأي علماء اليونان في سبب المرض، وتبعهم فيه كثير من العلماء العرب ممن كانوا قبل التميمي. 42 - مادة البقاء:54. 43 - معجم البلدان: ياقوت الحموي، دار صادر ، بيروت، 1977/1397: 272/2. 44 - مادة البقاء:138. 45 - السابق:138.

46 - تاريخ الأوبئة والمجاعات بالمغرب: محمد الأمين، منشورات كلية الآداب والعلوم الإنسانية، الرباط، 1992:

47 - السلوك لمعرفة دول الملوك: تقي الدين المقريزي، تحقيق: محمد عبد القادر عطا، دار الكتب العلمية، بيروت، الطبعة الأولى، 1997/1418: 265/2 وما بعدها.

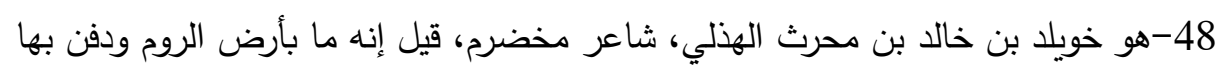

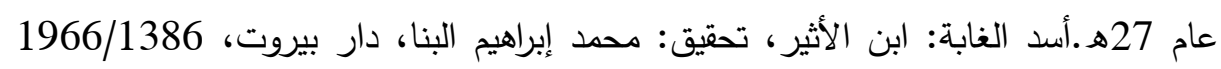
$.150 / 2$ : 49 - شعر الهذيليين: تحقيق: أحمد الزين، محمود أبو الوفا، دار الكتب الدصرية، الدار القومية للطباعة والنشر ، 1385/ 1965 : 1965. 50

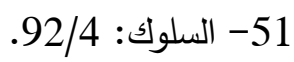
52 - بذل الماعون:238. 


\section{مجلةُ جامعةِ مِضْرَ للدِّراساتِ الإنسانيَّة (العلوم الاجتماعية والإنسانية) مجلد 2 العدد 2 يناير (2022)}

53- هو زين الدين أبو حفص عمر بن المظفر بن عمر المعري الكندي، الثهير بابن الوردي،

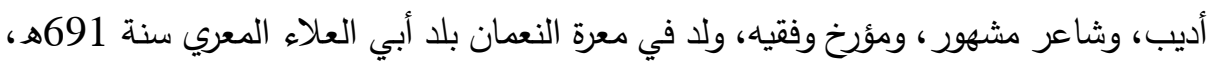
ونثأ بحلب، وولي قضاء منبج، ومات بالطاعون سنة 749 هـ وكون. 54 -بذل الماعون:232-236. 